\title{
Environmental Management Mechanisms in U.S. and Japanese Manufacturing Firms
}

\author{
Hidemichi Fujii (Corresponding author) \\ Graduate School of Environmental Studies, Tohoku University \\ 6-6-20 Aoba, Aramaki, Aoba-ku, Sendai 980-8579, Japan \\ Tel: 81-22-795-4309 E-mail: hidemichifujii@gmail.com
}

Kimbara Tatsuo

The Faculty of Commercial Sciences, Hiroshima Shudo University 1-1-1, Otsuka-higashi, Asaminami-ku, Hiroshima 731-3195, Japan

Tel: 81-82-830-1207Ｅ-mail: kinbara@shudo-u.ac.jp

Received: September 25, 2012

Accepted: October 10, 2012

Online Published: October 26, 2012

doi:10.5430/ijba.v3n6p13

URL: http://dx.doi.org/10.5430/ijba.v3n6p13

\begin{abstract}
This article analyzes the practices of environmental management and the relationship among environmental behavior, external factor, and performance in the United States and Japan. The objective of this paper is to analyze the mechanisms of environmental management of manufacturing firms in two countries. The causality framework used in this research has revealed the contrasting relationship among environmental behavior, external factor, and environmental and economic performance. The results demonstrated different causal processes in environmental management to reach a simultaneous/balanced environment and economy. These results can provide useful information to promote a firm's environmental behavior for sustainability.
\end{abstract}

Keywords: Corporate environmental management, Governance, Manufacturing sector, Japan, United States

\section{Introduction}

Work on environmental preservation has focused separately on individual issues, such as global warming, declining biodiversity, desertification and damage to the ozone layer, but these approaches are now flowing together into a single comprehensive concept of 'sustainable development' (WCED, 1987). Sustainable development, as agreed in general at the Earth Summit in 1992, seeks a way to simultaneously realize economic development and environmental preservation. In accordance with this vision, Porter (1991) proposed a new view for environmental investment in business, the Porter Hypothesis. He argued that adequate regulation stimulates technological innovation, improves environmental performance, enhances a firm's competitive advantage, and ultimately generates economic performance (Porter \& van der Linde, 1995). Regulations are necessary to achieve $80-95 \%$ reduction of greenhouse gases compared to the 1990 level (IPCC, 2007). To solve environmental issues such as global warming and bio-diversity protection, the role of firms as the primary economic actor is significant. This paper examines a number of the characteristics of environmental management and discusses the mechanisms of environmental management in relation to corporate governance.

We examine Japanese and U.S. manufacturing firms, focusing on environmental behavior for balancing economic and environmental performance. Structural equation modeling is used to analyze the process of environmental management. We investigate the causal relationship among environmental behavior, external factors, and performance. This paper defines environmental behavior as the practices and procedures that are directed toward reducing environmental burden caused by organizational activities.

Section 2 describes the institutional basis of environmental management. Section 3 is a literature review of the relationship between environmental and economic performance and its causal processes. Section 4 explains the objectives and research framework, and section 5 describes our dataset. Results on the parameters of structural equation modeling (SEM) are discussed in section 6, and section 7 summarizes the results of the study. 


\section{Environmental Management}

\subsection{Definition of Environmental Management}

The realization of sustainable development requires a paradigm shift from the conventional means of economic activities and company management in pursuit of economic objectives as a guiding principle, to new ways of managing activities that protect the natural environment. This paradigm shift virtually calls for changes in composition and the supply chain of raw materials, manufacturing processes and product design, and ultimately demands a new economic system. Therefore, the transformation to environmental management implies a system change (Schmidheiny, 1992). In this paper, a process of economic activity intentionally implemented to realize sustainability is termed environmental management.

The concept of sustainable development was accepted as a leading global principle, and firms are strongly expected to pursue environmental management. Since the middle of the 1990s, the 'Triple Bottom Line' concept has been stressed (Elkington, 1994). Companies are expected to fulfill certain duties as their corporate social responsibility (Kassinis \& Vafeas, 2007), not just for economic prosperity, but for social equity and environmental preservation.

Holding sustainable development as a value premise and initiating programs aiming towards its realization constitutes environmental management. Environmental management is carried out within the norm of sustainability and the realistic restrictions of corporate governance and an economic system. To further clarify this point, we will examine the mechanisms of environmental management and discuss their causal process in relation to corporate governance.

\subsection{Institutional Basis of Environmental Management}

Corporate governance is conceptually the control and management of a company and is generally defined as the relationships among the shareholders as investors, the board of directors, management and other stakeholders over control of the business (OECD, 2004). Because corporate governance indicates who holds company sovereignty and for what purpose business management should be carried out, the fundamental principle of corporate governance determines environmental investment behavior. Company decisions reflect the objectives of company sovereignty, or those with adjudicating power. There are broadly two views on corporate governance, and current environmental approaches by company management are based on these views.

These two views are called the shareholder approach and the stakeholder approach in this paper. There are similar models of categorizing corporate governance. Hall and Soskice (2001), who have compared economic systems in their research on diversity of capitalism, categorize corporate governance into coordinated market economy and free market economy. Two other classifications are the German model (German-style capitalism or Rhine Capitalism) and the Anglo-Saxon model (American-style capitalism) (Streeck, 2000; Zugehör, 2003).

These categorization theories have come about with discussions on the diversity of capitalism (Aoki \& Itami, 1994; Hall \& Soskice, 2001) or comparative management studies (Itami \& Aoki, 1985). In particular, comparative studies have made it clear that economic systems of different nations have different features depending on country-specific circumstances, indicating the diversity of capitalism. Variations are noted in market function, decision-making criteria, employment system, relationships between companies, and method of corporate governance. Like varied models of capitalism, categorized models of corporate governance should be understood as an idealized model. In reality, even in the same society, different forms of corporate governance exist. Not all companies are governed in the way exemplified in ideal models.

Historically, corporations originated in medieval Europe as a mechanism to concentrate capital. They allowed collecting and holding a quantity of capital through limited liability and securitization. There is a trustor-trustee relationship established between capital investors (shareholders) and business executives. Ultimate control is given to the investors, who are the trustors. Legislation for such a modern corporate system with limited liability of shareholders was established in the United Kingdom, Germany, France, the United States and Japan after the mid- $19^{\text {th }}$ century. However, closer historical study reveals that corporate governance has not been uniform across nations or regions, but shows variations in content. Today, Japan, the United States and Europe adopt different options for corporate governance as diversity of capitalism suggests.

In large German corporations, in particular, many of the shares are typically owned by banks and insurance and business companies, and tightly networked inter-firm relationships have been built (Zugehör, 2003). Workers have participated in business management quite extensively through legally supported Mitbestimmung (co-decision system). A system allowing harmonious labor-management relations is noticeable, and company management has focused on relations with stakeholders more than shareholder value. The German model is characterized by high 
levels of coordination and cooperation and has created a corporate governance style unique to Germany. This model has become a distinctive economic order as it is defined by German socioeconomic conditions.

In contrast, the United States has a distinctive model of corporate governance that was developed through particular socioeconomic conditions. These conditions were significantly different from the circumstances underlying the formation of corporate governance in Continental Europe and Japan. In 1919 the Michigan Supreme Court held that "A business corporation is organized and operated primarily for the profit of stockholders. The discretion of the directors is to be exercised in the choice of means to attain that end" (Nevins \& Hill, 1957).

\subsection{Environmental Behavior}

As clear in the above description, the shareholder approach is characterized by emphasizing the lawful legitimacy of ownership, and within this framework, the corporate social role is defined. In short, the shareholder approach focuses on who owns the company while the stakeholder approach centers on a viewpoint of company objectives, concerning for whom the company exists. The basis for argument on the legitimacy of governance is quite different for the two approaches.

Company environmental undertakings are determined in accordance with economic system and corporate governance, and these features are reflected in the implementation of environmental policy and practices. Under different corporate governance, different environmental behavior is observed. To understand the difference in mechanism, different corporate aims must be noted. The shareholder approach prioritizes economic benefit to shareholders. When a corporation is owned and controlled by such shareholders, the objective of business management is maximization of shareholder value. Return on equity (ROE) is used as key criteria for decision-making, which means the environment is treated as rather secondary or a set of constraints. The natural environment such as the air is regarded as free goods that firms can consume without cost in spite of negative externalities. As a result, strict public rules to prevent environmental damage are more likely to be imposed on the shareholder approach. Regulatory and compulsory environmental policy will be toughened against behavior inherent in the shareholder approach. Then government and firms often conflict with each other. With compulsory regulation, companies show reactive and passive environmental behavior.

In contrast, the stakeholder approach seeks to coordinate requests from all stakeholders, including their objectives, interests and security, and in principle, seeks solutions agreeable to each party's interests regarding the economy, society and environment. Sustainable nature is also a stakeholder request to be satisfied. In the early 1990s Sweden, Norway and Denmark levied a tax on carbon emissions. As the stakeholder approach emphasizes coordination among stakeholders, it also allows some flexibility for sustainability in addressing the environment. In the stakeholder approach, environmental protection becomes an obvious subject, as it is treated as a requirement of stakeholders such as the consumer and community.

The two approaches also differ concerning environmental cost, reflecting the purpose of firms. As in the agency model, environment-related cost is regarded as inefficiency, and internalization of the cost is rejected. But, regarding this cost categorized as external diseconomy, it should be emphasized for sustainability that "Environmental damage costs must be internalized wherever possible" (OECD, 1998).

A model of corporate governance in any nation or region was not always fixed. That is, E.U. countries and Japan did not always historically adopt the stakeholder approach. After the Enron and WorldCom scandals in 2001, the Sarbanes Oxley Act was established in the United States in 2002. Aiming to reform corporate governance, the law (the Public Company Accounting Reform and Investor Protection Act) requires tougher accountability for internal control and stipulates strict obligations and penalties. As a result, the shareholder approach has become more dominant in a capital market where ownership and free competition are highly regarded.

The stakeholder approach has some ambiguity in the structure and content of corporate governance (Barney, 2002). Among multiple stakeholders, the question is who in principle can exercise controlling power, and how. Controlling power and how it is exercised depend on the social, economic, and organizational conditions in which firms are situated. Although the stakeholder approach in its nature is relatively compatible with sustainable society, the criteria for corporate behavior are not clearly defined.

\section{Literature Review}

This section discusses previous research on the relationship between the economy and the environment and mechanisms of environmental management. Porter suggested that properly designed environmental regulations can encourage technological development, promote firms' environmental activities, and enhance environmental performance (Porter, 1991; Porter \& van der Linde, 1995). Technological development and improvement in resource 
productivity can increase a firm's competitive advantage and enhance its overall economic performance. This hypothesis includes a perspective about the causal process of environmental management and important phases to be revealed. It suggests research issues, such as the relationships between regulation and innovation, innovation and economic performance, and economic and environmental performance.

Previous research can be divided into four categories. First, regarding environmental regulations, policy decisions, such as environmental taxation, become central issues (Palmer et al., 1995). This category examines the relationship between environmental regulations and environmental performance. When an environmental tax is introduced one question is about the tax impact in terms of gross domestic product or investment cost. Interests focus on which regulations are more economically effective (Brunnermeier \& Cohen, 2003).

The second category investigates the relationship between economic and environmental performance. Empirical studies have attempted to assess whether a balanced relationship can exist between environmental and economic performance (Russo \& Fouts, 1997; Hart \& Ahuja, 1996; Konar \& Cohen, 1997; Wagner, 2001). Some researchers argue that a positive relationship does not exist between economic and environmental performance (Walley \& Whitehead, 1994) or that benefits may occur only under specific conditions (Rugman \& Verbeke, 1998; Palmer et al., 1995). Multiple regression analysis was used to examine the relationship; research findings in the United States (Hart \& Ahuja, 1996; Konar \& Cohen, 1997; Al-Tuwaijri et al., 2004), the United Kingdom (Thomas, 2001), Germany (Wagner et al., 2002) and Japan (Fujii et al., 2012) were presented.

The third category of existing literature focuses on environmental practices that can improve economic performance (Nehrt, 1998). For this purpose, adopting a resource-based view (RBV) to shed light on strategy and organizational capabilities is useful. Aragón-Correa and Sharma (2003) argue that environmental management strategy based on contingency theory and dynamic capability of RBV is critical for improving environmental performance. Florida (1996) and Shrivastava (1995) discussed whether or not a proactive environmental strategy enhances economic performance. Evidence also shows that total quality management (TQM), ISO 14001, and participatory management can increase environmental efficiency (Shrivastaba, 1995; DeSimone \& Popoff, 1997). Schaltegger and Synnestvedt (2002) also considered green supply chains and environmental management systems (EMS).

Fourth, corporate environmental management is implemented as part of business activities in the economic system. Thus, the decision to invest in an environmental undertaking is done within the framework of an economic system and a corporate governance system in a specific society as we described in section 2 .

This corporate governance and economic system as institutions are the basis of environmental management and constrain its investment decision. In the previous study of institutional economics and comparative management, two approaches are typical types. Each approach shows distinctive characteristics in its behavior. One takes it for granted that firms are owned by shareholders, and as a natural result, they pursue profit maximization. Ultimate control is with the shareholders. The other approach to corporate governance emphasizes why a firm exists and responds to the requests of various groups of stakeholders and satisfies their requirements, such as assurance of employment, preservation of nature, profit seeking, and safe living. Control exists in the coalition of stakeholders.

Consequently, there is a different pattern in environmental management, which is closely related to corporate governance and economic system. The shareholder approach makes decisions based on the principle of profit maximization and market-orientation. Alternatively, the stakeholder approach based on relation-oriented strategy tends to emphasize the coordination of interests of each stakeholder and satisfy the aspirations of all stakeholders. Environmental management is influenced by various factors (Johnstone \& Labonne, 2009). We focus our research on mechanism and interpret the mechanism from the perspective of corporate governance.

\section{Research Framework}

This paper analyses the characteristics and causal relationship among external factors, behavior, and performance in the environmental management of Japanese and U.S. manufacturing companies. Figure 1 shows the analysis framework, which is composed of 1) external factors, 2) firm factors of environmental strategy and organization, and 3) performance factors. Performance includes environmental and economic performance; in this framework, external environment, organizational activities, and performance are assumed as causal processes. For example, socially responsible investment (SRI) in a stock market enhances environmental efforts that can increase the economic value of the firm. In response to such market requirements, organizational activities in environmental conservation and environmental strategy will be enhanced. These factors in Figure 1 are treated as latent variables in the structural equation modeling; the latent variables are not directly measured but depend on individual observed variables. We define five latent variables as follows. 
a) External factor: This is the concept that influences environmental strategy and management from outside. Government, community and customer/market are important outside stakeholders (Henriques \& Sadorsky, 1996; Florida, 1996). From these outside stakeholders, we set three operational indicators for external factor: government requirements, community requirements, and customer requirements.

b) Environmental strategy: Strategy is decision making rules and a framework that integrates goals, policy and a series of conduct standards into a consolidated system. This defines the choice of policy and direction of actions. We use as an operational variables priority of environmental management, organizational initiatives that include top leadership, voice of environmental managers, and employee participation.

c) Organization: The third concept is organization, which consists of technological environmental practices and managerial system. Technological environmental practices include development and design, manufacturing, and waste and recycling. The managerial system includes obtaining ISO 14001 certification, environmental reporting, and adoption of environmental accounting. These are measured as adopted, preparing, and not preparing. Each is given score of 3, 2 or 1, respectively.

d) Environmental performance: This is the result realized or expected results of the environmental behavior. WBCSD showed several indicators for environmental performance (WBCSD, 2000). Firms use their own appropriate indicators to measure their efficiency. Hart and Ahuja (1996) used the Toxic Release Inventory (TRI) emission and its change rate of TRI emission in their analysis. TRI emission data and environmental management ranking are frequently used (Corderio \& Sarkis, 1997; Konar \& Cohen, 1997). It is often difficult to obtain exact data for waste water, air exhausted and $\mathrm{CO}_{2}$ emission from individual firms. In this paper, we used score of perception on these indicators in the 5-point Likert scale.

e) Economic performance: This is the outcome of activities in economic terms. Return on assets (ROA), ROE, and Tobin's Q ratio are often used in the analysis (Hart \& Ahuja, 1996; Russo \& Fouts, 1997; Wagner et al., 2002) to verify the Porter hypothesis. We used perception data to get consistency of variables and indicators. A 5-point Likert scale was used to measure the degree of activities in the indicators of economic effects, cost benefit, customer relationships, joint problem solving, and customer claims.

$<$ Insert Figure 1 Here >

\section{Data}

For analyzing the environmental management of firms, we used a pre-structured framework with data obtained from a questionnaire survey conducted in 2007. Questionnaires were mailed to 1,100 firms in Japan during November and December 2007, resulting in 318 effective answers. Telephone interviews using the same questionnaire were conducted in the United States with 1,000 U.S. firms from May to July 2007, resulting in 167 effective answers. The effective response rates of Japanese and United States were $28.9 \%$ and $16.7 \%$, respectively. We used these samples for analysis in this paper. Information was obtained from the responses in the questionnaire using a 5-point Likert scale. An exception of measurement is the organizational indicator of the environmental management system, which includes environment reports, ISO 14001 certification, and environmental accounting. The evaluation was conducted to describe the status of indicators if practices are in (i) the implementation stage $(=1)$, (ii) the preparation stage $(=0)$, or (iii) without a plan to formulate $(=0)$.

The external factors consist of three indicators: (1) government directions on environmental measures; (2) requests from the community; and (3) requests from customers. The environmental strategy consists of indicators of (1) environmental measures as a priority of corporate management; (2) top leadership; (3) influence of the person in charge; and (4) employee participation. The set of indicators pertaining to the organization are (1) environmental measures and activities in the production process; (2) environment-oriented product development and design activities; (3) recycling of waste products and other recycling activities; (4) environment report; (5) ISO 14001 certification; and (6) introduction of environmental accounting. Indicators 1, 2, and 3 are related to the technological level of environmental measures, while indicators 4,5 , and 6 refer to the environmental management systems of firms.

Investigating the relationship of environmental strategy and organization to performance, we divided performance into two categories: environmental and economic. To use consistent indicators with organizational variables, we obtained perception data to measure economic and environmental performance. Environmental performance includes (1) level of water pollution control efforts; (2) level of air pollution control efforts; and (3) level of $\mathrm{CO}_{2}$ reduction efforts. Alternative indicators for economic performance include (1) benefits from environmental management; (2) overall return of environmental cost; (3) claims by customer (as scored in inverse); (4) collaboration with customers 
in problem solving; and (5) stability of relations with customers. Based on the data, we show the average score of each observed variable in Table 1. Abbreviations are explained in Appendix.

$<$ Insert Table 1 Here>

From Table 1, we find that Japanese firms recognize the pressure from market and consumers more than pressure from the government and community. In contrast, U.S. firms recognize pressure from the government more than from the market and community. This difference is reflected in the strict government regulation and conflicting relationship between government and firms in the United States. Additionally, most Japanese firms (93\%) obtain ISO 14001 certification, but U.S. firms show a low ratio (28\%) for ISO 14001 certification. The motivation to obtain ISO 14001 is to impress an eco-friendly image on consumers, making favorable terms for companies that pursue a green supply chain. Because of these advantages, Japanese firms have been motivated to obtain ISO 14001 certification.

Collaboration between firms such as suppliers or customers is relatively strong in Japanese firms, but not in U.S. firms. In U.S. firms, it is lowest score in the 5 indicators, which shows that Japanese firms have a closer relationship with suppliers or customers to solve environmental issues they face. We can recognize relatively strong cooperative interdependence among firms in Japan.

\section{Results and Discussion}

The results of structural equation modeling in Japanese and U.S. firms are described in Figure 2 and Figure 3, respectively. The score in Figure 2 and Figure 3 shows standardized path coefficients, which are defined from -1 to 1 . If the standardized path coefficient is significantly positive, there is a positive relationship from independent variable to dependent variable. The comparative fit index (CFI) and root mean square error of approximation (RMSEA) represent goodness of model fitting, which is better if CFI is close to one and RMSEA is close to zero.

In Figures 2 and 3, we observe a significantly positive effect from external factors to environmental strategy in both countries. However, external factors are not significantly related to an organization's environmental behavior in Japan while a significantly positive coefficient is observed in the U.S. result. Consequently, external factors can be understood to significantly influence an organization's environmental behavior in the United States but not in Japan. Environmental strategy has a significantly positive effect on an organization's environmental management system. This result implies that strengthening environmental strategy enhances environmental behavior. When top management plays a role in environmental strategy, it stimulates increased environmental practices and participatory efforts by organization members.

Then, we observe the significantly positive effect from organizational practices to environmental performance in Japan, but non-significant negative results in the United States. This result shows that organizational practices do lead to the improvement of environmental performance in Japan, but do not in the United States. There is a distinctive causal process because the influence and role of external factors on an organization vary in Japan and the United States.

Viewing these differences in the mechanism in two countries, it does not hold that the economic development stage is clearly different in two countries when we take into consideration the fact that technological availability, the level of industrial activity, and international political and economic environment does not create much difference. It is therefore plausible to think that different mechanisms are caused at a level deeper than the social and economic system. We need to investigate the behavioral pattern defined by the objectives and method of management.

$<$ Insert Figure 2 Here $>$

$<$ Insert Figure 3 Here $>$

One consistent fact with this result is that strict environmental regulation incurs the reactive, end-of-pipe pollution treatment activity (Lanjouw \& Mody, 1996). End-of-pipe treatment is needed to pay additional cost in non-production processes and usually does not contribute to cost reduction. Thus, it does not produce positive outcome to the economic performance from environmental investment. Additionally, in U.S. firms, it is generally understood that government regulation is stronger and compulsory, and firms tend to respond to this pressure with minimum cost. The strict environmental regulation caused reactive actions of firm to avoid a lawsuit risk and market reputation. At the same time, limited actions, which are evoked at the subunit of organization with narrow responsibility of person-in-charge, respond mainly to adapt to regulation and reduce the environmental risk. Therefore, environmental performance under strict regulation will not increase.

U.S. firms with systematic functional specialization of job tend to appoint a person responsible for an environmental department to address issues. This kind of appointment is reflected in the high ratio of firms that have EMS in the 
United States, according to OECD (2010) study. In contrast to this kind of appointment, the acquisition of an ISO 14001 certificate is obviously less in U.S. firms as compared to Japan and the European Union (ISO Survey). This difference implies that there is a person responsible for managing environmental issues with limited authority and responsibility for handling environmental issues. His or her influence is limited in the organization and not on the entire process of organization because the responsibility and power of such a manager are specific and restricted.

In contrast, as shown as coordinated market economy, Japanese firms need to take positive action to satisfy the requirements of stakeholders to improve the quality of the environment in the whole process of organization. This is because external factors have a relatively strong effect on the top management level of organization in Japanese firms with a stakeholder approach to corporate governance. Thus, stakeholder requirements influence corporate strategy and ISO 14001 or other activities such as reduce, reuse and recycle (3R), which are frequently introduced. As a result, from the top of the organization to the line worker is a consistent, coordinated action to solve issues. It is not compulsory, regulatory influence that takes specific action for improvement, but overall organizational policy. It is implemented as the extension of TQM, which seeks to improve efficiency and reduce cost (Shrivataba, 1995). More than half of the environmental innovations is process innovation to improve efficiency and energy saving (Rennings \& Rammer, 2009). Consequently, organizational policy tends to generate better improvement of environmental performance that involves the participation of all members.

Next, there is a non-significant and negative effect from organization to economic performance in Japan but non-significant and positive effect in the United States. The relationship in the two countries does not show the same consistent results. To simultaneously achieve expected results in environmental and economic performance, organizational resources and capabilities are usually the basis of strategy and competitive advantage; resources and capabilities are obtained in the long-term process of activities. Previous studies emphasized path dependence in environmental management (Corderio \& Sarkis, 1996; Florida, 1996; Arragón-Correa \& Sharma, 2003). Environmental management will pass through certain stages to become active (Hart, 1996).

Seeing our results, we cannot support the Porter hypothesis regarding the organizational process in which government regulation leads to innovation that will, in turn, cause environmental performance as well as economic performance. The U.S. firm case, which displayed significant impact on organizations from external factor, has not generated positive environmental and economic performance. In contrast, the case of Japan, which showed non-significant and weak impact on organizations from external factors, suggests the importance of environmental strategy as a causal mechanism to improve performance. We emphasize that the importance of corporate governance is the reason for the different mechanisms in the two countries. Corporate governance as an institutional base can combine these results and provide logical consistency. In Japanese firms with a stronger stakeholder approach, external factor on environmental management is recognized stronger at the top level of organization as compared with U.S. firms. Company policy and strategy then more reflect this pressure in their action. In the United States, even though environmental strategy is recognized as an important factor, it does not mean positive organizational practices for environmental performance (Gutowski et al., 2005; Popp, 2006). That is, there are limited practices to improve performance because a shareholder approach emphasizes profit for shareholders and tends to avoid, as much as possible, cost for environmental investment.

\section{Conclusions}

The causality framework used in this research has revealed the relationship among environmental behaviors, external factor, and environmental and economic performance. From the empirical analysis in Japan and the United States, we demonstrated the causal process of environmental management in order to promote a simultaneous/balanced environment and economy. This mechanism can provide useful information to promote a firm's environmental behavior for sustainability in two countries.

Our results suggest that government needs to consider its economic system and corporate governance to ensure action for sustainability. There is an overt limitation in the conventional approach. Through understanding these mechanisms of management in the firm and its difficulties to approach a more sustainable society, we will be able, by specific measures such as demand side policy, to overcome some of the difficulties constrained by institutional conditions. Then, we will create a more effective process of environmental management and achieve higher quality of environmental performance.

As described in corporate governance, firms in Japan and the United States have different backgrounds for environmental programs, and their active environmental policies also vary. Each region or nation has undertaken its own environmental program in accordance with its distinctive corporate governance model and economic system. Companies and their economic, social and cultural base cannot be separated. Therefore, environmental management 
practices and investment are deeply related in their institutional system. Environmental investment decisions are made with the control of corporate governance.

The relationship between economic and environmental performance in Japan is significantly positive, but not significant in the United States. The effect of strategy and practices on environmental performance is perceived stronger in Japan than in the United States. Based on these results, the theoretical and practical importance of this study becomes evident. The environmental strategy of firms that decide the goal and investment play an important role in balancing between the economy and environment. Thus, if environmental strategy is sufficiently proactive, maintaining consistent organizational behavior that positively impacts environmental and economic performance will be effective. Through environmental strategy, we expect organizational efforts will be enhanced. When government environmental regulations directly require firms to implement environmental measures to reduce specific burden, organizations will easily become passive. When incentives for firms are weak, expecting them to persist in their environmental efforts will be unrealistic. However, when firms are encouraged to have clear environmental objectives and policies, organizational initiatives are strengthened.

The environmental management system and action depend on environmental strategy constrained by corporate governance, which has critical importance for striking a balance between the environment and economy. To enhance this process, promoting a high level of environmental consciousness in the market and society is necessary. This heightened that consciousness can more positively guide a firm's responses to external factors.

Since the 1990s, the two approaches to corporate governance have made a step towards sustainability. The triple bottom line or global compact as a broad basis of CSR became a guideline for international firms. However, companies have been taking on environmental measures under the restrictions of their corporate governance and economic system. Our analysis showed that the mechanism of environmental management is obviously different in Japan and the United States. However, both require further reform to achieve progress towards a sustainable society. Environmental policy still has crucial importance for reaching this sustainable society. Further research needs to investigate the environmental efforts of firms in developing countries, as well as in developed countries. Such an analysis will clarify causal relationship to the stages of economic development.

\section{References}

Al-Tuwaijri, S.A., Christensen, T.E., \& Hughes II, K.E. (2004). The relations among environmental disclosure, environmental performance, and economic performance: a simultaneous equation approach. Accounting, Organizations and Society, 29, 447-471. http://dx.doi.org/10.1016/S0361-3682(03)00032-1

Aoki, M. (1994). The Japanese as a system of attributes: A survey and research agenda. In M. Aoki \& R. Dore (Eds.), The Japanese firm: Sources of competitive strength. Oxford publisher. http://dx.doi.org/10.1093/acprof:oso/9780198288152.003.0002

Aoki, M., \& Itami, H. (1985). Economics of the Firm, Iwanami Shoten, Japan.

Aragón-Correa, J.A., \& Sharma, S. (2003). A contingent resource-based view of proactive corporate environmental strategy. Academy of Management Review, 28(1), 71-88. http://dx.doi.org/10.5465/AMR.2003.8925233

Barney, J. B. (2002). Gaining and sustaining competitive advantage $\left(3^{\text {rd }}\right.$ ed.). Prentice-Hall. http://dx.doi.org/10.1108/02635570410537462

Brunnermeier, S.B., \& Cohen M.A. (2003). Determinants of environmental innovation in U.S. manufacturing industries. Journal of Environmental Economics and Management, 45(2), 278-293. http://dx.doi.org/10.1016/S0095-0696(02)00058-X

Corderio, J.J., \& Sarkis, J. (1997). Environmental proactivism and firm performance: evidence from security analyst earnings forecasts. Business Strategy and the Environment, 6, 104-114. http://dx.doi.org/10.1002/(SICI)1099-0836(199705)6:2<104::AID-BSE102>3.0.CO;2-T

DeSimone, L.D., \& Popoff, F. (1997). Eco-Efficiency. MIT Press.

Elkington, J. (1994). Towards the sustainable corporation: Win-win-win business strategies for sustainable development. Sloan Management Review, 36(2), 90-100.

Florida, R. (1996). Lean and green: The move to environmentally conscious manufacturing. California Management Review, 39(1), 80-105. http://dx.doi.org/10.1225/CMR068

Fujii, H., Iwata, K., Kaneko, S., \& Managi, S. (2012). Corporate environmental and economic performances of Japanese manufacturing firms: Empirical study for sustainable development. Business Strategy and the Environment (forthcoming).

Grant, R.M. (1991). The resource-based theory of competitive advantage: Implications for strategy formulation. 
California Management Review, 33(3), 114-135.

Gutowski, T., Murphy, C., Allen, D., Bauer, D., Bras, B., Piwonka, T., ... Wolff, E. (2005). Environmentally benign manufacturing: Observations from Japan, Europe and the United States. Journal of Cleaner Production, $13,1-17$. http://dx.doi.org/10.1016/j.jclepro.2003.10.004.

Hall, P., \& Soskice, D. (eds.) (2001). Varieties of Capitalism: Institutional Foundations of Comparative Advantage. Cambridge publisher. http://dx.doi.org/10.1093/0199247757.001.0001

Hart, S. L. (1995). A natural-resource-based view of the firm. Academy of Management Review, 20(4), 986-1014. http://dx.doi.org/10.2307/258963

Hart, S.L., \& Ahuja, G. (1996). Does it pay to be green? An empirical examination of the relationship between emission reduction and firm performance. Business Strategy and the Environment, 5(1), 30-37. http://dx.doi.org/10.1002/(SICI)1099-0836(199603)5:1<30::AID-BSE38>3.0.CO;2-Q

Henriques, I., \& Sadorsky, P. (1996). The determinants of and environmentally responsive firm: An empirical Approach. Journal of Environmental Economics and Management, 30, 381-395. http://dx.doi.org/10.1006/jeem.1996.0026

Intergovernmental Panel on Climate Change (IPCC). (2007). IPCC's 2007 Fourth Assessment Report, IPCC, Genève, Switzerland.

Johnstone, N., \& Labonne, J. (2009). Why do manufacturing facilities introduce environmental management systems? Improving and/or signaling performance. Ecological Economics, 68(3), 719-730. http://dx.doi.org/10.1016/j.ecolecon.2008.06.003

Kassinis, G., \& Vafeas, N. (2006). Stakeholder pressures and environmental performance. Academy of Management Journal, 49(1), 145-159. http://dx.doi.org/10.5465/AMJ.2006.20785799.

Klassen, R.D., \& McLaughlin, C.P. (1996). The impact of environmental management on firm performance. Management Science, 42(8), 1199-1213. http://dx.doi.org/10.1287/mnsc.42.8.1199

Konar, S., \& Cohen, M.A. (1997). Information as regulation: The effect of community right to know laws on toxic emissions. Journal of Environmental Economics and Management, 32(1), $109-124$. http://dx.doi.org/10.1006/jeem.1996.0955

Lanjouw, J.O., \& Mody, A. (1996). Innovation and the International Diffusion of Environmentally Responsive Technology. Research Policy, 25, 549-571. http://dx.doi.org/10.1016/0048-7333(95)00853-5

Nehrt, C. (1998). Maintainability of first mover advantages when environmental regulations differ between countries. Academy of Management Review, 23(1), 77-97. http://dx.doi.org/10.2307/259100

Nevins, A., \& Hill, F.E. (1957). FORD, Expansion and Challenge 1915-1933. Arno Press.

North, D. (1990). Institutions, institutional change and economic performance. Cambridge University Press.

Organization for Economic Cooperation and Development (OECD). (1998). Eco-Efficiency, OECD, Paris, France.

Organization for Economic Cooperation and Development (OECD). (2004). OECD Principles of Corporate Governance, OECD, Paris, France.

Palmer, K., Oates, W.E., \& Portney, P.R. (1995). Tightening environmental standards: The benefit-cost or the no-cost paradigm? Journal of Economic Perspectives, 9(4), 119-132. http://dx.doi.org/10.1257/jep.9.4.119

Popp, D. (2006). Innovation in Climate Policy Models: Implementing Lessons from the Economics of R\&D. Energy Economics, 28(5-6), 596-609. http://dx.doi.org/10.1016/j.eneco.2006.05.007

Porter, M.E. (1991). America's green strategy. Scientific American, 264(4), 96.

Porter, M.E., \& van der Linde, C. (1995). Green and competitive: Ending the stalemate. Harvard Business Review, 73(5), 120-134.

Rennings, K., \& Rammer, C. (2009). Increasing energy and resource efficiency through innovation - an explorative analysis using innovation survey data. Czech Journal of Economics and Finance, 59(5), 442-459.

Rugman, A.M., \& Verbeke, A. (1998). Corporate strategies and environmental regulations: An organizing framework. Strategic Management Journal, 363-375. http://dx.doi.org/10.1002/(SICI)1097-0266(199804)19:4<363::AID-SMJ974>3.0.CO;2-H

Russo, M.V., \& Fouts, P.A. (1997). A resource-based perspective on corporate environmental performance and profitability. Academy of Management Journal, 40(3), 534-559.

Schaltegger, S., \& Synnestvedt, T. (2002). The link between "green" and economic success: environmental management as the crucial trigger between environmental and economic performance. Journal of Environmental 
Management, 65(4), 339-346. http://dx.doi.org/10.1006/jema.2002.0555

Schmidheiny, S. (1992). Changing course: A global business perspective on development and the environment. The MIT Press. http://dx.doi.org/10.1002/bse.3280020108

Shrivastava, P. (1995). Environmental technologies and competitive advantage. Strategic Management Journal, 16, 183-200. http://dx.doi.org/10.1002/smj.4250160923

Streeck, W. (2000). The Transformation of Corporate Organization in Europe: An Overview, Paper presented at the First Conference of the Saint-Gobain Foundation for Economic Research, Paris, November 2000.

Thomas, A. (2001). Corporate environmental policy and abnormal stock price returns: An empirical investigation. Business Strategy and the Environment, 10, 125-134. http://dx.doi.org/10.1002/bse.281

Wagner, M. (2001). A review of empirical studies concerning the relationship between environmental and economic performance what does the evidence tell U.S.? Center for Sustainability Management.

Wagner, M., Phu, N.V., Azomahou, T., \& Wehrmeyer, W. (2002). The relationship between the environmental and economic performance of firms: and empirical analysis of the European paper industry. Corporate Social Responsibility and Environmental Management, 9(3), 133-146. http://dx.doi.org/10.1002/csr.22

Walley, N., \& Whitehead, B. (1994). It's not easy being green. Harvard Business Review, 72(3), 46-47.

World Business Council for Sustainable Development. (2000). Eco-efficiency: Creating more values with less impact. WBCSD, 1-32.

World Commission on Environmental Development (WCED). (1987). Our Common Future: The Brundland Report on Environment and Development. Oxford University Press.

Zugehör, R. (2003). Die Zukunft des rheinischen Kapitalismus: Unternehemen zwischen Kapitalmarkt und Mitbestimmung. VS Verlag.

Table 1. Average scores of questionnaire survey in Japan and U.S

\begin{tabular}{|c|c|c|c|c|c|}
\hline \multirow[t]{2}{*}{ Latent variable } & \multirow[t]{2}{*}{ Observed variable } & \multicolumn{2}{|c|}{$\begin{array}{c}\text { Japanese firms } \\
\mathrm{N}=318\end{array}$} & \multicolumn{2}{|c|}{$\begin{array}{c}\text { U.S. firms } \\
\mathrm{N}=43\end{array}$} \\
\hline & & Mean & S.D. & Mean & S.D. \\
\hline \multirow{3}{*}{$\begin{array}{l}\text { External } \\
\text { Factor }\end{array}$} & Administration (GOV) & 3.78 & 0.90 & 3.95 & 1.01 \\
\hline & Community (COM) & 3.62 & 0.93 & 3.68 & 0.94 \\
\hline & Customer (CUS) & 4.03 & 0.91 & 3.55 & 1.16 \\
\hline \multirow{4}{*}{$\begin{array}{c}\text { Environmental } \\
\text { Strategy }\end{array}$} & Leadership (LDS) & 4.35 & 0.71 & 3.99 & 0.91 \\
\hline & Participation (PAR) & 4.02 & 0.75 & 3.91 & 0.81 \\
\hline & Person in charge (VOI) & 3.89 & 0.79 & 4.13 & 0.87 \\
\hline & Priority of EMS (PRI) & 4.40 & 0.70 & 3.90 & 0.90 \\
\hline \multirow{6}{*}{ Organization } & ISO 14001 (ISO) & 0.93 & 0.25 & 0.28 & 0.45 \\
\hline & Environmental report (REP) & 0.65 & 0.48 & 0.35 & 0.48 \\
\hline & Environmental accounting (ACC) & 0.53 & 0.50 & 0.36 & 0.48 \\
\hline & Manufacturing process (PRO) & 4.53 & 0.57 & 2.77 & 1.18 \\
\hline & Eco-products (DSG) & 4.33 & 0.76 & 2.33 & 1.33 \\
\hline & Reuse and recycling (RCY) & 4.59 & 0.66 & 4.29 & 0.88 \\
\hline \multirow{3}{*}{$\begin{array}{l}\text { Environmental } \\
\text { Performance }\end{array}$} & Water pollution (WWAT) & 4.40 & 0.80 & 4.45 & 0.72 \\
\hline & Air pollution (WAIR) & 4.37 & 0.77 & 3.92 & 0.83 \\
\hline & $\mathrm{CO}_{2}$ emissions $(\mathrm{CO} 2 \mathrm{E})$ & 4.28 & 0.74 & 3.93 & 1.11 \\
\hline \multirow{5}{*}{$\begin{array}{c}\text { Economic } \\
\text { Performance }\end{array}$} & Stable relationship (STA) & 4.44 & 0.59 & 4.38 & 0.80 \\
\hline & Claims (CLA) & 3.37 & 0.67 & 3.51 & 1.15 \\
\hline & Collaboration (SOL) & 3.93 & 0.85 & 4.34 & 0.71 \\
\hline & Positive benefit (BEN) & 3.73 & 0.90 & 4.24 & 0.90 \\
\hline & Overall return (OVER) & 2.91 & 0.95 & 4.36 & 0.74 \\
\hline
\end{tabular}




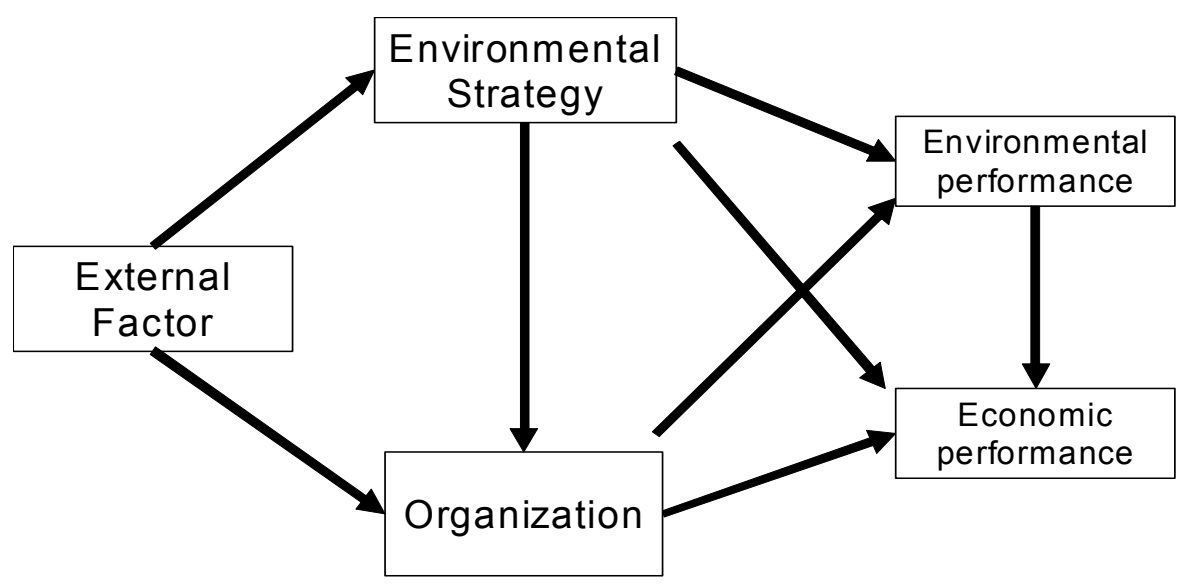

Figure 1. Framework of analysis

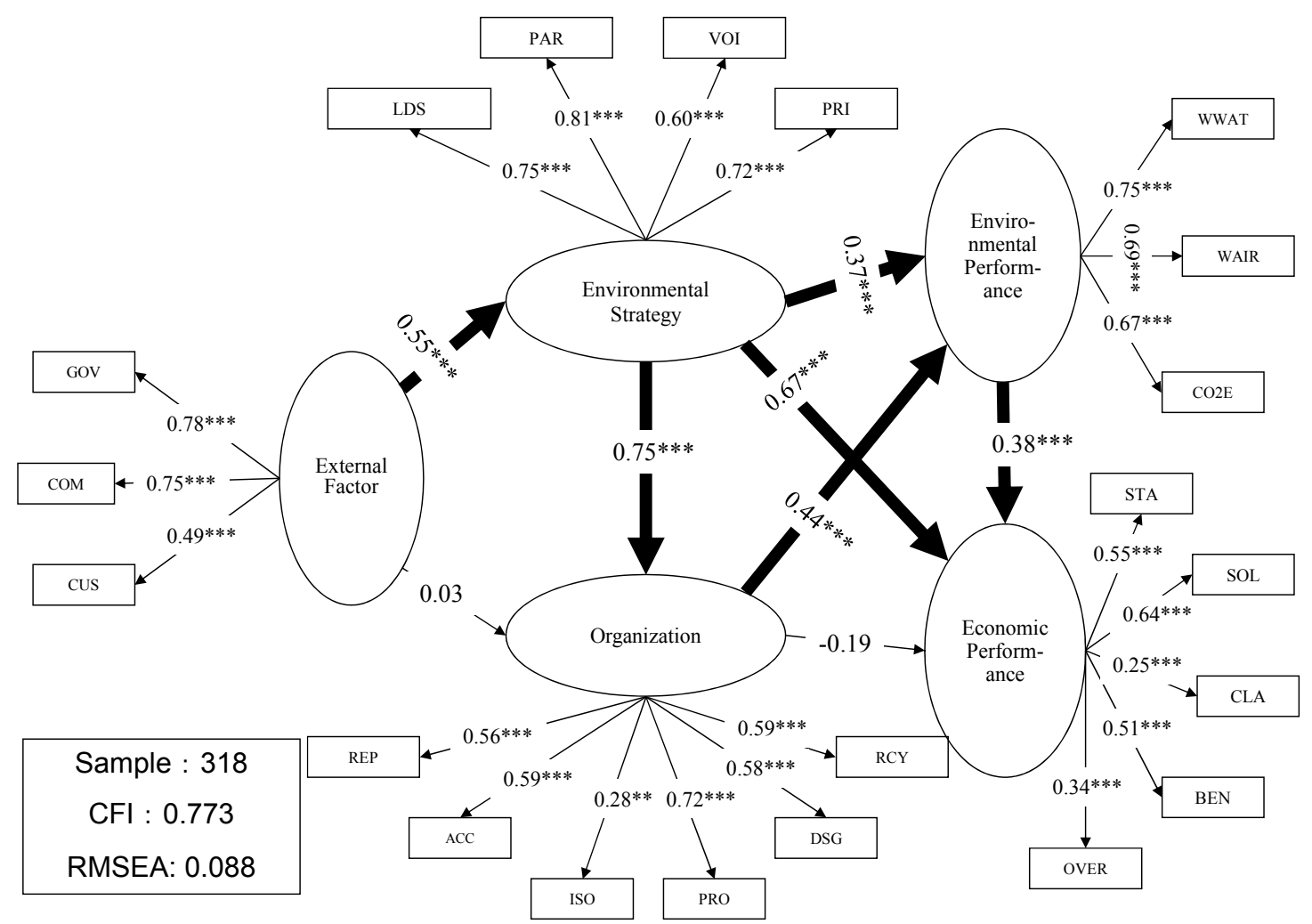

Figure 2. Results of 318 Japanese firms

$*, * *, * * *$ represent significance at the 10,5 , and 1 per cent level, respectively. 


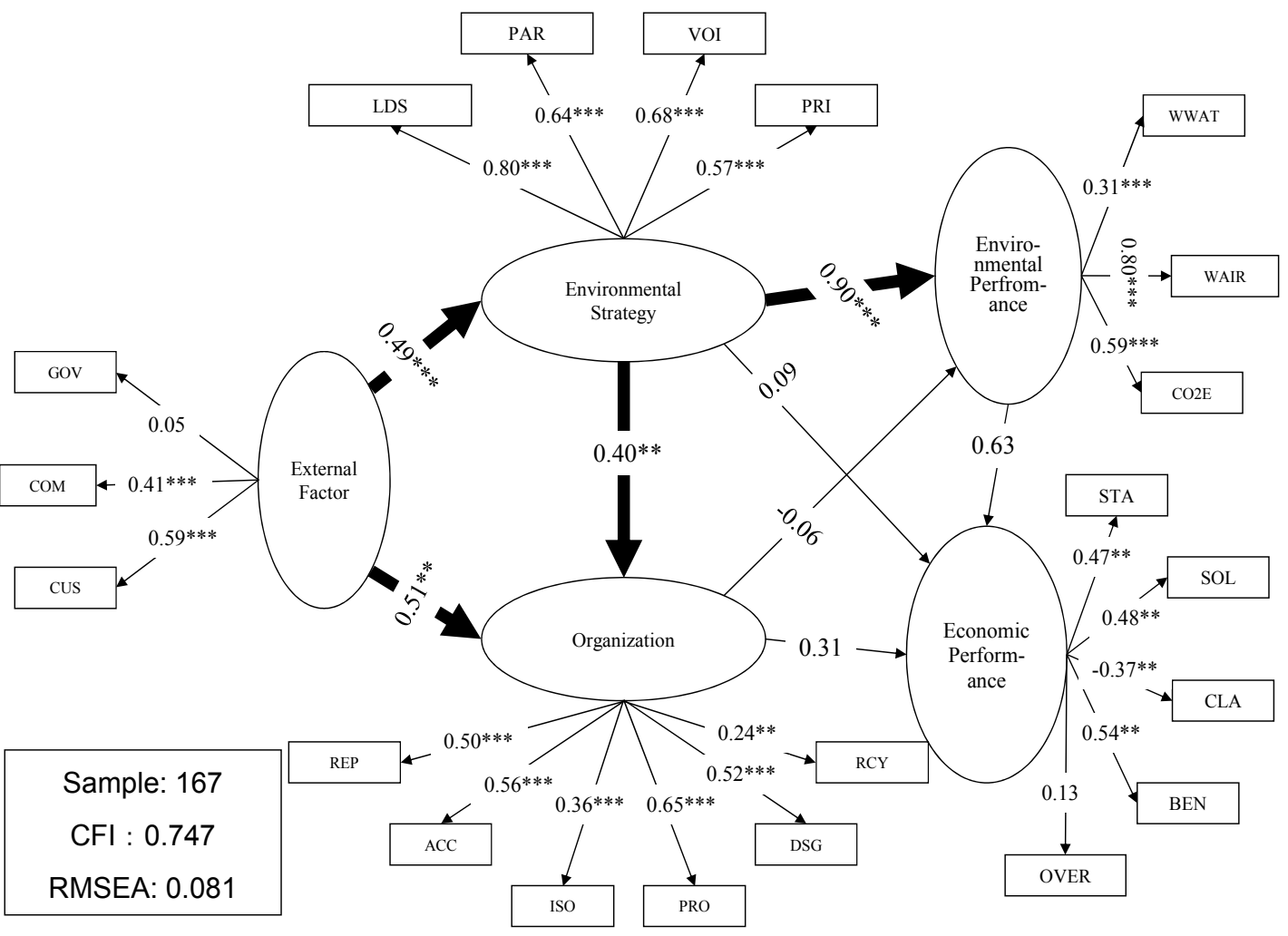

Figure 3. Results of 167 U.S. firms

$*, * *, * * *$ represent significance at the 10,5 , and 1 per cent level, respectively.

Appendix. Details of the questionnaire survey

$1=$ Strongly disagree, $3=$ Neither agree nor disagree, $5=$ Strongly agree; 2,4 are intervals

\begin{tabular}{|c|l|}
\hline GOV & Governmental environmental regulations and mandates require significant efforts to meet. \\
\hline COM & Community demand for environmental performance is strong. \\
\hline CUS & Customers demand environmentally friendly products and services. \\
\hline LDS & Leadership on environmental issues by top management is strong. \\
\hline PAR & Employee participation in environmental issues is strong. \\
\hline VOI & Person in charge of environmental issues has a strong "voice" in the organization. \\
\hline PRI & Environmental impact is a priority when making business decisions. \\
\hline REP & Your company has obtained ISO 14001 certification. Yes $=1$, No $=0$ \\
\hline ACC & Your company has an environmental report or a sustainability report. Yes $=1, \mathrm{No}^{\prime}=0$ \\
\hline PRO & $\begin{array}{l}\text { Your company makes an effort to improve environmental performance in the } \\
\text { manufacturing process. }\end{array}$ \\
\hline DSG & Your company produces eco-friendly design products. \\
\hline RCY & Your company implements reuse and recycling practices. \\
\hline WWAT & The level of waste water treatment in your company is good. \\
\hline WAIR & The level of air emissions reduction in your company is good. \\
\hline CO2E & Your company is active in reducing CO ${ }_{2}$ emission. \\
\hline STA & Your company's market base consists of stable, long-term customers. \\
\hline CLA & $\begin{array}{l}\text { Customers complain about you company's products and performance. } \\
\text { (In this study, we use inverse score of CLA, } \rightarrow 5,5 \rightarrow 1 \text { ) }\end{array}$ \\
\hline SOL & Your company often cooperates with buyers to solve problems. \\
\hline BEN & $\begin{array}{l}\text { The company's efforts to improve environmental practices have had a positive effect on } \\
\text { financial benefit. }\end{array}$ \\
\hline OVER & Financial returns from environmental efforts outweigh costs of such efforts. \\
\hline
\end{tabular}

